\title{
Going Global: The Role and Effect of Leadership Styles in PT Bunga Mawar Indonesia
}

\author{
Siti Rohaida Mohamed Zainal ${ }^{1}$, Roazian Md Nor $^{2}$ and Yudi Fernando ${ }^{1}$ \\ ${ }^{1}$ School of Management, Universiti Sains Malaysia, Malaysia \\ ${ }^{2}$ School of Business, Universiti Sains Malaysia, Malaysia
}

\begin{abstract}
It is widely acknowledged that among all determinants of employment outcomes, leadership is viewed as an important predictor with a central role (Carli, 1990). It has been long held within the humanistic management perspective that different types of leadership style eventually are leading towards different outcomes. In this era of globalization, the role of leadership in determining the internalization pathways for the company is even more crucial. Due to many environment changes, companies decide to inject a new perspective into their management styles. The issue of globalization for example, has lead many companies to divert their focus to the issues of sustainability. This paradigm shift requires management to solicit the subordinates' inputs in decision making and/or allow them to ensure that the management receive a warm support from the employees which is embarking to the sustainability journey, it actually begin from the internal groups. Thus, this paper discusses the leadership style of senior manager in medical wastes business in Indonesia. By using the qualitative approach with case study method, there were 13 semi-structured interviews with 35 questions based on the topic used to investigate the role of leader's leadership styles. Later, all data was transcribed and coded systematically. Based on the results of the interviews, the case analysis is presented, thus at the end, this paper will conclude by recommendations for management of PT Bunga Mawar.
\end{abstract}

Keywords: leadership, medical waste, green management

\section{Introduction}

\section{Preview of the Case}

Although PT Bunga Mawar is the only company authorized by the government to process medical waste in Indonesia, yet PT Bunga Mawar has been facing leadership problem that is quite unnoticeable to outsiders. For example, in terms of making decisions, PT Bunga Mawar cannot decide on its own with regards to doing business in
Indonesia. All decisions are made from the parent company in Kuala Lumpur. It is absolutely difficult since PT Bunga Mawar has to follow the parent company policies that maybe different from the business environment in Indonesia. Indeed, PT Bunga Mawar needs to make a few policy changes, including the standard operation procedure (SOP). With this, policies need to be updated according to the cultural, economic, social and political situations of the present location of the company. 
Despite the fact that this matter has been presented several times before the shareholders in Kuala Lumpur, it seems no action has been taken by the headquarters. Perhaps, the headquarters company has assessed PT Bunga Mawar as a subsidiary company that causes financial losses. The parent company needs to cover PT Bunga Mawar operating cost since inception. It is because of the high operation cost that has not been considered by the parent company during the start-up of the company. However, this condition may not be applicable anymore. High operating cost may be due to transportation and plant capacity which had not been maximized yet. They can only process three to four tonnes per day although it is expected to process 14 tonnes per day. Rapid changes of economic, social, political situations and customer driven demands are the previous strategy that has been set by the Malaysia's headquarter which does not work in the company.

Bunga Raya Malaysia as parent company does not put much emphasis on this issue. They are more interested in dollars and cents rather than the process needed to get the money. The centralized approach becomes a dilemma to the company's growth. Mr. X as the leader of the company is also losing credibility from his employees. He cannot lead and inform them about what actually happens between PT Bunga Mawar and Bunga Raya Malaysia. Apart from the internal barriers, PT Bunga Mawar also faces external barriers such as lack of enforcement from the Indonesian government.

The government has enacted the Law of 32 which states that "any person who intentionally perform acts that are beyond the result of ambient air quality standard, quality standard water, sea water quality standard, or standard criteria of environmental damage shall be sentenced to life imprisonment, or 3 (three) years to maximum of 10 (ten) years and a fine of not less Rp3.000.000.000, 00 (three billion rupiah) and maximum Rp10, 000,000,000, 00 (ten billion rupiahs)". Even though the law had been stated, there are no cases whereby any actions had been taken against any hospitals and healthcare facilities that does not treat medical waste in a proper manner. The focus of this study is on how Mr X can lead the medical waste company in becoming better in Indonesia.

\section{History of PT Bunga Mawar}

Bunga Raya Malaysia Sdn. Bhd. is a subsidiary company of Pantai Holdings Bhd, Malaysia's frontier healthcare provider owned by Khazanah Group of Company. The company owned a 15 years concession project in Malaysia together with two (2) other companies to operate and manage medical waste, cleaning and maintenance services to all government hospitals divided by regions namely northern, middle and eastern coastal and southern regions. The company is also entrusted to provide pertinent consultancy services to countries in the Middle East, India and few others as parts of their business activities and go-green initiatives.

The meetings of the Board of Directors of Bunga Raya Malaysia Sdn. Bhd. held on the 29th March 2006 and 6th September 2006, approved the investment of 30 years concession project for the provision of medical waste and hazardous waste management and also incinerator services in the West Java Province, Indonesia. During the concession between Bunga Raya Malaysia Sdn. Bhd. and the Provincial Government of West Java (PGWJ), Indonesia defined the scope of contract as the former to provide and implement the comprehensive 'cradle to grave' concept of medical and hazardous waste management and services for the Province. The PGWJ pledged to support the project through policy, regulations and enforcement. This covers from the practices of sorting and collection of waste source (in hospitals), transportation, treatment (incineration process) and final disposal. On the hazardous waste portion, PT Bunga Mawar has been working with the UEM 
Environment Sdn. Bhd. (UEME) for possible subcontracting.

The investment is recognized as a new subbusiness unit (SBU) and a potential new market and revenue development for Bunga Raya Malaysia Sdn. Bhd. in its expansion for a new income flow. The medical waste management and incinerator services are recognized as the core strength in Bunga Raya Malaysia Sdn. Bhd. spectrum of service offerings. The negotiation process, including the feasibility study hauled the partnership over two years for the deal to conclude. The project came to light due to the feasibility business propositions which had resulted in both push and pull factors, played by both interest parties. PGWJ is on it pursuits for reputable project proponents for its infrastructure development plans, matching the Bunga Raya Malaysia Sdn. Bhd.'s needs for new growth as to enhance their streams of income.

\section{Going Abroad - Why Indonesia}

As stated in The Jakarta Post dated 17th June 2009, entitled, 'Powerless governors see no Future in Vague Autonomy', for regents and mayors, autonomy is a source of authority and inspiration in dealing with affairs in their own region. Governors however, seem to have no real constituents or territories. Contrasting the previous (centralistic era) position of governors as representatives of the central government in provinces and as mediators in regional matters, this has sparked critics that direct gubernatorial election is superfluous. The 2008 gubernatorial elections in east Java cost the government almost Rp 1 trillion. People are beginning to question the role of governors in the roles as heads of the administration hierarchy. The 2004 Regional Law failed to define the authority of governors especially in relation to regents and mayors. Law has granted the heads of provinces dual role as both heads of autonomous regions and governors are expected to have coordination and supervision functions over the regency and municipal administration, but regents and mayors refuse to report to them because they are elected directly by the people. There is no clear line between the function of the regency or municipal and the provincial and central government which was a very complex matter that the country's state administrative experts had not been able to address.

The immature concept of regional autonomy policies had contributed to the inconsistency of legal framework. As long as all stakeholders have not reached consensus over the maturity of Indonesians regional autonomy, any revision to existing regulations will not produce expected outcomes. Therefore it is clearly seen that with the power of decentralization, it is difficult for PT Bunga Mawar to make decisions as it needs to go thoroughly a few stages before it comes to the consensus. Bunga Raya Malaysia Sdn. Bhd. also needs to socialize in terms of not only lobbying the central government but also the provisions, regional government, cities and sub districts. As it has been known that the West Java has 9 states which are known as "Kota" and 17 other regions. With the 26 cities, the West Java is divided within 620 sub-districts. In the sub-districts, there are 1576 comprises developed and 4301 undeveloped areas.

Joint development with local partner in Indonesia is opted as the most strategic choice to penetrate the Indonesian market as it will favor and fit well with the Bunga Raya Malaysia Sdn. Bhd.'s asset management and resource allocation for the project. A joint venture company, Bunga Raya Malaysia Sdn. Bhd., with a Penanaman Modal Asing (PMA) status has been incorporated, representing PT Bunga Mawar Sdn. Bhd. (owned by Malaysian shareholders) with 95\% share and PT Bunga Melur (which is Indonesian-based) for the remaining 5\% share. PT Bunga Melur is an investment arm of PGWJ, Indonesia which is holding a 70\% majority share.

The operating environment is highly attractive to Bunga Raya Malaysia Sdn. Bhd. to be part of this venture. Technical expertise 
and high reputation in the management of medical waste and incinerator services has thus far positioned Bunga Raya Malaysia Sdn. Bhd. in its very strategic edge. Through the knowledge it has given in the industry and exclusivity rights on the project, Bunga Raya Malaysia Sdn. Bhd. can expect secure and consistent earnings during the concession period. The project has been given top priority in PGWJ list and is closely monitored and observed through monthly coordination meetings between both parties. The favorable government restructuring scheme enforceability and acquiescent legal framework particularly on socio-cultural and environmental aspects and expectations, are further harmonized by perceived stability in the political scenario for the most part, evidently seen on the foreseen positive development following the recent postdecentralization of power and autonomy to provincial and local governments in the year 2000. This should result in more conducive investment climate for foreign investment into the country. Moreover, the project is also now regarded as of the national interest for environmental protection and go-green initiatives and it is under direct involvement and supervision of Kementerian Linkungan Hidup (KLH) through its local offices, i.e, Badan Pengendalian Lingkungan Hidup Daerah (BHLHD), West Java and Health Division of PGWJ to streamline the management of medical waste in the province.

Due to this matter, even though PT Bunga Mawar has been approved and signed, a concession for a 30-year contract with the PGWJ seems insufficient, as PT Bunga Mawar needs to have support not only from the PGWJ governor but also support coming from the regional, cities and sub-districts. These multi-layers of administrative ordeals will delay the implementation and enforcement of Law 32 because each region has its own administration team and so do the cities and sub-districts. Even though, all government sectors have acknowledged the existence of PT Bunga Mawar, it seems like the company has problems in which the law does not act accordingly. The bottom line is that the law exists but it fails to be enforced due to the political issues in which transparency is difficult to be achieved.

\section{Literature Review}

\section{The Concept of Management}

The concept of management emerges when people realize that, in order to perform as an organization, it requires an effective system. This system is essential since organization simply cannot operate on its own. According to Robbin (2010), to advance from a technical position to a managerial one is difficult because, not only does one have to retain one's technical knowledge and competence, but one must also develop new managerial knowledge and skills. Today, there are many management scholars who firmly believe that it is this set of managerial skills, coupled with technical skills, that enables managers to manage effectively.

Robbin (2010) also further explains that without these fundamental skills, "managers cannot effectively plan, direct, control, or assess work activities" (p.31).In addition, there are many managers who are promoted predominantly for their technical skills, so they may not have the managerial skills necessary to perform their tasks effectively. Researchers such as Richardson and Lynes (2007), Orr (2004) and Johnson (2000) concluded that people will not attempt tasks if they believe that they do not have the abilities and skills essential to perform the tasks effectively. Therefore, in order to effectively manage the work, it actually starts with the people's management. The management has to be clear about the direction of the company from three aspects namely strategic, operational and tactical aspects.

Employees have to be well guided to ensure the mission and visions are accomplished effectively and efficiently. In the recent scenario, in which all the companies are moving towards green management, it 
actually requires a serious attention from the management perspectives. The paradigm from the traditional management's view has to be shifted to the green management and this can only be done when the organization is ready to convert their traditional factors of production to the green factors of production. Thus, the organizations have to revisit their factors of production such as the land, labour, capital, entrepreneur and knowledge to suit the demands of the green management.

\section{Green Management - The Role of Leader}

Duke (2000) concluded that understanding leadership is like watching a parade, whereby individuals tend to see upon where they stand. As a result, conclusions tend to be drawn based on what has been observed. Similarly, in leadership field, there have been studies from many perspectives to capture the best sight to conclude about leadership. In the late 1960s, the "styles" of a leader have become a main concern among the behavior investigators. Singh-Sengupta (1990) has defined the word 'styles' as a pattern of regularities in the act of leading. However, in the early twenty-century, researchers tend to expand their studies by examining all the traits or styles that a leader should possess. Study conducted by Pearce (2004) manages to draw a very interesting outcome. He concluded that leadership style is divided into four categories, which are directive, transactional, transformational and empowering. He also explained that leaders who apply a more symbolic leadership styles such as team vision, emotional engagement is being classified as effective leaders. Regardless of the definition and classification of leaders, generally, leaders have to ensure that the management is able to integrate initiatives in the leadership styles in order to be viewed as an effective leader (Nattrass \& Altomare, 1999).

In the green scenario, it is important for leader to understand how their values and professional goals reflect underlying human motivations and shape the subsequent attitudes, speech, and actions of personnel (Begley, 2006). The leader needs to transfer the green knowledge to the organization. Shrivastava (1994) had argued that the transformation to ecological sustainability requires a new form of ecocentric management and leadership. This is due to the difference between environmental leadership and traditional leadership theory, which had been earlier discussed by both Ackley and Begley (2010). Further, Ackley and Begley (2010) have discussed the difference between environmental and traditional leadership. The green leader's challenge is not only to be a leader in the organization where he has been assigned, but also to be an environmental leader. The roles and responsibilities for an individual in this position are different than a traditional leader as this individual must be able to make decisions that not only influence the organization population but also address a litany of environmental problems (Gordon \& Berry, 2006) by incorporating the ecological issues into the organization culture (Ackley \& Begley, 2010).

Therefore, to be recognized as green organization, leaders are expected to design more rigorous objectives in all levels of management plans generally, researchers' and practitioners' views of what green management truly entails can fall at any point along a continuum, ranging from simple and basic environmentally-friendly programs that prevent further harm, to complex and demanding strategic initiatives that help to restore the environmental damage that has been done in the past. Cisco and Motorola are among others who have been awarded the green leadership in the industry. For example Cisco has hired a vice president of green engineering that is committed to the environment. The objective is to play a leadership role in the development and consistent application of environmental standards (Cisco, 2011). Motorola has recognized the country's leading green power purchasers for their commitment and contribution to help advance the development of the US's 
voluntary green power market (Csrwire.com, 2010).

\section{Methodology}

On the basis of the case study protocol proposed by Yin (2009), the specific information has been collected prior to the site visits such as a survey instruments, role of people to be interviewed, the events to be observed, and other documents to be reviewed when on site. Apart from that, the main source of data available is through indepth interviews while communication was arranged by telephone, fax and email. The case study had been conducted for about three weeks. Two site visits were conducted for data collection. The first visit was held on $12^{\text {th }}$ December 2010 to $23^{\text {rd }}$ December 2010. The first visit is aimed to obtain the administrative point of view in the management office in Bandung. Secondly, the site visit was held on the $14^{\text {th }}$ January 2011 until $18^{\text {th }}$ January 2011, this was to investigate the waste management process in the operational plant which is located in Cikampek, West Java. The second visit has been conducted where the incidence of emerging issues, that cannot be found in the cover of the administrative office (high operational cost \& plant capacity), is examined.

The type of interview is the in-depth interview where the interviewer can ask the informants about the facts of a matter as well as their opinion about events. The informants also can propose their own insights into certain occurrences and may use such propositions as the basis for further inquiry (Yin, 2009). Fourteen informants were selected for interview sessions (Table 1 and Table 2). The details of the interviewees are as follows.

Table 1: The List of Respondent in the First Visit

\begin{tabular}{|l|l|c|}
\hline Code & \multicolumn{1}{|c|}{ Position } & Date \\
\hline R01 & Director & $14 / 12 / 2010$ \\
\hline R02 & Finance and Accounting Staff & $15 / 12 / 2010$ \\
\hline R03 & Marketing Executive & $16 / 12 / 2010$ \\
\hline R04 & Head of Department of Environmental Management & $17 / 12 / 2010$ \\
\hline R05 & Head of Ministry of Health, Bandung city & $20 / 12 / 2010$ \\
\hline R06 & Business Consultant & $21 / 12 / 2010$ \\
\hline R07 & Debt Collector & $22 / 12 / 2010$ \\
\hline R08 & Customer A (Healthcare Institution) & $23 / 12 / 2010$ \\
\hline R09 & Customer B (Healthcare Institution) & $23 / 12 / 2010$ \\
\hline
\end{tabular}

Table 2: The List of Respondent in the Second Visit

\begin{tabular}{|l|l|c|}
\hline Code & \multicolumn{1}{|c|}{ Position } & Date \\
\hline R10 & Executive Engineer & $14 / 01 / 2011$ \\
\hline R11 & Operator & $17 / 01 / 2011$ \\
\hline R12 & Tax Accounting Staff & $18 / 01 / 2011$ \\
\hline R13 & General Affair Executive & $18 / 01 / 2011$ \\
\hline
\end{tabular}

Each interview session was conducted from an hour to two hours. The case study is not complete without visiting the plant where the incinerator is located. Approval from senior managers about the appropriate date must be granted. The incinerator does not operate on a daily basis. The date to visit the plant was postponed to next month. On 
January 14th 2011 until 22nd January 2011, the executive engineer at the plant had the opportunity to pay a site visit at the plant and also describes the incinerator process undertaken. The interview results were recorded and notes were taken during the interview. There were 13 semi-structured interviews with leadership questions based on the topic that has been investigated. The data was transcribed and coded systematically to represent themes and subthemes. The data had been analyzed and grouped into themes and subthemes.

\section{Results}

The crisis of leadership has made PT Bunga Mawar run business without any strong individual character to act as leader. This is due to the fact that no one in the senior management has leadership attitude in the company. They are frequently busy, which makes them always unavailable at the office. For example, the company has experienced a number of delayed payments because the senior managements are not around (only senior managers and director are authorized to issue the payment cheques). As another example, the leadership of senior management is also needed to represent the company when he must deal with prospective 'golden consumers', and in reality, the senior managements are not always willing to deal face- to-face with customers.

They asked plant manager to recover costs and expenses for spare part replacement and so on. Indeed, the reimbursement is not just a part of plant authority. They have filed an application for replacement spare parts by fax or e-mail to our office in Bandung. It was received by us. An accounting and finance department, it was done all procedures but they need to wait. Since our senior managers were not around. I have mentioned from the beginning, only two people can sign the cheque payments. They are $M r . X$ and $Y$. It is impossible for us to reimburse quickly if one of them did not stay here (IB24-R03).
Our director has been invited by director of client, but he did not want to come, you know who will come? It is me, an only ordinary staff of this company, it will be a disappointment. It was never considered by management's of PT. Bunga Mawar. Actually it is a big advantage that we can meet with the director, we can talk more. Are they happy when we come? Really it is would be an honor. ....although they are happy, but when there are strategic decisions that must be taken between the level of director or senior manager, and it should be decided at that moment, I think it will be inconvenience for the customer (IB24-R04).

Communication between management and staff are not good. Although we did communicate with the director or senior manager, but still it was not enough, we have convinced them to meet the customer and dealing face to face. The customer who has strategic position in his company only willing to deal with somebody in same level that's what makes us sometimes feel uncomfortable. When the manager or director gives disposition to us, we head to head with the director while we were at the level of staff feels it is not good, but from the management itself is simple just give that authority to staff (IB24-R04).

The management should also make a point to meet with the customers to find out the root of problems that have been experienced at the operational level. They also could discuss this matter with employees through formal and informal meetings to improve medical services. Suggestions and ideas from consumers need to be of due concern.

It is very important, because every time I went to the hospital they tell me about the complaints ... we need one position in company to follow up the customer complaints, so our waste is not ups and downs. That one, then also for top management of us should be more aware to PT. Bunga Mawar. They don't have to be 
here every day, I also understand they are busy. But when there are need urgently that require them to come and stand by here, they do not exist (IB21-R03).

The employees hope the management to walk in their corridor, to perform the task function properly. It is not us talking like this, but we did get the impact when we have to move not only as a sales consultant, but at a certain moment we also have to represent them, to make a decision, indeed for the signature would not be possible in the financial or letters of cooperation, but in a strategic decision, we should hold. That becomes a burden for us, it's nothing actually, but crucial in front of the customer (IB21-R04).

Maybe they should pay more attention to the customers' needs and employees' wellbeing (IB20-R04).

\section{Discussion and Recommendation}

Leadership style plays a pertinent role to guide a company into a better direction. If the senior management does not want to pay a visit and interact directly with the 'golden customer' it will inhibit the company in getting an employment contract. The management will not know much about the market in Indonesia when they only come and work behind a desk. Senior managers are also required to be responsive to consumers' growing demands. Besides, the management also needs to have, and show concern to their employees' wellbeing. Leadership is a vital managerial skill. The senior manager is expected to have the entrepreneurship spirit and innovative idea to cater better service to the customers. Besides, the communication skill to motivate employees is deemed to be an essence. The senior manager could also convey the message from the headquarters to the subordinates. He must also open himself to learn something new about customers' behaviour, environmental issues, and managerial skills. As an expatriate, the senior manager also needs to understand the local business culture.
Overall, this study found that the leadership styles of a leader can be either push or pull factors for an organisation. However, this study specifically found that in the mission of going abroad in medical waste industry, the leader has to practice the transactional leadership style. Based on the findings, it is suggested that transactional leadership styles is the most appropriate leadership style which acts as the push factor leading the PT Bunga Mawar to Indonesian Market. The transactional leadership style allows the senior manager to reward the subordinate based on performance. He needs to provide some clear structure and job description so the aim that should be achieved by the subordinates is clear. The transactional leadership style promotes discipline and good organisation. Although the transactional leader is well-understood to have a high level of discipline at work, it does not mean he would frighten employees with a punishment that will be granted if the subordinates fail in performing their duties.

Indeed, transactional leaders are able to motivate and provide alternative solutions to any problems that arise. Sometimes, the senior manager is needed to make field-visits and not to just sit behind a desk. The senior manager must also be prepared to establish a good relationship with clients and customers so that he becomes a figure who can represent the company. With these leadership skills, he is able to bring the company to move forward. As with any study, this study is not free from limitations. To the extent that there are many other variables contributing to the successfulness in the mission of going abroad, this study is keen into analyzing the role of leadership styles of the leaders in the organisation. Therefore, the findings must be read with this caveat. Since this study is applying a case study approach, it focuses only on the Indonesian setting, thus, there is some risk in generalising the results to all types of leadership styles in different settings of an organisation or even to a different country. 


\section{References}

Ackley, C. R. \& Begley, P. T. (2010). "The Changing Face of Purpose-Driven School Administration: Green School Leadership," Advances in Educational Administration, Volume 11, 377-396.

Begley, P. T. (2006). "Self-knowledge, Capacity and Sensitivity: Prerequisites to Authentic Leadership by School Principals," Journal of Educational Administration, 44(6). 570-589.

Cisco (2011). "Corporate Citizenship Report 2007: Cisco and the Environment," data accessed on 010411, data retrieved at http://newsroom.cisco.com/dlls/2008/ekits /g1_Cisco_Green_Leadership_030308.pdf?PO SITION=LINK\&COUNTRY

SITE=us\&CAMPAIGN=NewsAtCiscoGreen200 8\&CREATIVE=Cisco+Green+Leadership\&REF ERRING_SITE=

NewsatCiscoPressKit

Csrwire.com (2010). Motorola Receives Second Annual EPA Green Power Leadership Award, data accessed on 010411, data retrieved at

http://www.csrwire.com/press_releases/30 899-Motorola-Receives-Second-Annual-EPAGreen-Power-Leadership-Award

Gordon, J. C. \& Berry, J. K. (2006). "Environmental Leadership Equals Essential Leadership: Redefining Who Leads and How," New Haven, CT: Yale University.

Haden, S. S. P., Oyler, J. D., \& Humphreys, J. H. (2009). "Historical, Practical, and Theoretical Perspectives on Green Management: An Exploratory Analysis," Management Decision, 47 (7). pp. 1041-1055.

Johnson, S. D. (2000). "The Economic Case for High Performance Buildings," Corporate Environmental Strategy, Vol. 7 No.4, pp.35061.

Lawrance, S. \& Jordan, P. (2009). "Testing and Explicit and Implicit Measure of Motivation," International Journal of Organizational Analysis, 12, 2, 103 - 120.
Massoud, J. A., Daily, B. F. \& Bishop, J. W. (2011). "Perceptions of Environmental Management Systems: An Examination of the Mexican Manufacturing Sector," Industrial Management \& Data Systems, 111(1). pp. 519.

Natrass, B. \& Altomare, M. (1999). "The Natural Step for Business. Wealth, Ecology, and the Evolutionary Corporation," British Columbia: New Society Publishers.

Orr, D. W. (2004). "Can Educational Institutions Learn? The Creation of the Adam Joseph Lewis Center at Oberlin College," in Barlett, P.F., Chase, G.W. (Eds).Sustainability on Campus: Stories and Strategies for Change, The MIT Press, Cambridge, MA, pp.159-75.

Robbins, S. P. (2010). 'Organizational Behavior,' Upper Saddle River, New York: Pearson. Education Inc.

Rosenblatt, V. (2011). "The Impact of Institutional Process, Social Networks, and Culture on Diffusion of Global Work Values in Multinational Organizations," Cross Cultural Management: An International Journal, 18, 1, $105-121$.

Richardson, G. R. A. \& Lynes, J. K. (2007). "Institutional Motivations and Barriers to the Construction of Green Buildings on Campus: A Case Study of the University of Waterloo, Ontario ," International Journal of Sustainability in Higher Education, 8 (3). 339354.

Shrivastava, P. (1994). "Ecocentric Leadership in the 21st Century," Leadership Quarterly, 5(3). 223-226.

Srivastava, P. \& Frankwick, G. L. (2011). "Environment, Management Attitude, and Organizational Learning In Alliances," Management Decision, 49, 1, 156 - 166.

Yin, R. K. (2009). Case Study Research Design and Methods, Fourth Edition, SAGE Publications, Inc . 